\title{
Gender-specific adverse effects of mono-ethylhexyl phthalate on steroidogenesis in immature granulosa cells and rat Leydig cell progenitors in vitro
}

\section{Konstantin Svechnikov*, Irina Svechnikova and Olle Söder}

Department of Woman and Child Health, Pediatric Endocrinology Unit, Karolinska Institute and University Hospital, Stockholm, Sweden

\section{Edited by:}

Raimo Voutilainen, University of

Eastern Finland, Finland

\section{Reviewed by:}

Jorma Toppari, University of Turku, Finland

Giorgio Radetti, General Hospital of Bolzano, Italy

\section{${ }^{*}$ Correspondence}

Konstantin Svechnikov, Department of Woman and Child Health, Pediatric Endocrinology Unit, Q2:08, Karolinska Institute and Hospital, Astrid Lindgren Children's Hospital, S-17176

Stockholm, Sweden.

e-mail: konstantin.svechnikov@ki.se
Di-(2-ethylhexyl) phthalate, one of the phthalates most widely distributed in the environment, causes reproductive toxicity that is attributable to the action of its primary metabolite, mono-(2-ethylhexyl) phthalate (MEHP). Here, we have investigated the effects of MEHP on steroidogenesis by primary cultures of rat Leydig cell progenitors and immature granulosa cells. This phthalate stimulated basal steroidogenesis and steroidogenic acute regulatory protein (StAR) expression in both types of steroidogenic cells. However, when MEHP was incubated with $(\mathrm{Bu})_{2} \mathrm{CAMP}$, steroid production was increased in granulosa cells and suppressed in Leydig cell progenitors, a process associated with up-regulation of StAR expression. Our data suggest that MEHP exerts gender-specific adverse effects on the hormonal function of the developing gonads. This may be involved in the development of pathological conditions including disorders of prenatal sex development that may attenuate future reproductive health.

Keywords: Leydig cell progenitors, immature granulosa cells, MEHP, steroidogenesis, StAR

\section{INTRODUCTION}

An increased incidence of disorders of sex development (DSD), such as hypospadias and cryptorchidism as well as testicular cancer and poor semen quality during the last decades in humans have been attributed to the influence of endocrine disruptors (ED). These compounds constitute a heterogeneous group of xenobiotics of anthropogenic origin which can mimic natural hormones, inhibit the action of hormones, or alter their biosynthesis and/or metabolism (Lottrup et al., 2006).

Phthalates, including the widely used plasticizer di-(2ethylhexyl) phthalate (DEHP), are components of many plastic products, such as food wraps, toys, and some medical devices (e.g., tubings, bags for intravenous infusions, blood transfusion, and dialysis equipment; Thomas and Thomas, 1984). DEHP is loosely held with the plastic polymer and can easily be released into the environment (Koch et al., 2006). High concentrations of phthalate metabolites were detected in the urine of women of childbearing age (Blount et al., 2000), a finding that can be associated with extensive use of personal care products (e.g., skin creams and nail polish) containing phthalates. Children on dialysis are suggested to be one of the most vulnerable groups for phthalates exposure, because they may receive high levels of phthalates from dialysis tubing (Loff et al., 2000; Brock et al., 2002). Further, in this context, children and women of childbearing age were demonstrated to have higher urinary levels of phthalates than other groups (Blount et al., 2000). Moreover, maternal phthalate exposure during pregnancy has been associated with decreased anogenital distance (AGD) in male infants (Swan et al., 2005), a finding suggested to be due to attenuation of androgen production by the fetal testis.
Experiments on animal models have demonstrated that DEHP causes reproductive toxicity in both prenatal and postnatal stages of development. This effect was attributed to its primary metabolite, mono-(2-ethylhexyl) phthalate (MEHP; Sjoberg et al., 1986; Dostal et al., 1988; Gray et al., 2001). This mono-phthalate impairs the function of steroid-producing gonadal cells, such as Leydig and granulosa cells in both in vivo and in vitro experimental paradigms. MEHP was observed to inhibit the stimulation of testosterone production in primary cultures of rat Leydig cells by luteinizing hormone (LH; Jones et al., 1993) and the activation of steroidogenesis by human chorionic gonadotropin (hCG) in the MA-10 Leydig cell line (Dees et al., 2001). We have recently demonstrated that MEHP decreased hCG-activated steroidogenic acute regulatory protein (StAR) expression, a process that was associated with reduced transport of cholesterol into mitochondria and attenuated androgen production in immature and adult Leydig cells (Svechnikov et al., 2008). Similarly, MEHP was reported to attenuate progesterone production by follicle stimulating hormone (FSH)-stimulated primary cultures of rat granulosa cells in vitro (Treinen et al., 1990) and chronic administration of DEHP to rats inhibited sex hormone production in immature female rats in vivo and ex vivo (Svechnikova et al., 2007). In addition, MEHP was demonstrated to suppress estradiol production by granulosa cells through direct inhibition of transcription of the aromatase (CYP19) gene (Lovekamp and Davis, 2001).

However, the mechanism(s) underlying the action of MEHP on developing Leydig and granulosa cells at their early stages of differentiation has not yet been investigated. Thus, the aim of the present study was to examine the effects of MEHP on steroidogenesis in progenitor Leydig cells and immature granulosa cells isolated from 20-day-old male and female rats. 


\section{MATERIALS AND METHODS MATERIALS}

Dulbecco's modified Eagle's medium (DMEM) - Ham's nutrient mixture F-12 (supplemented with L-glutamine and HEPES), bovine serum albumin (BSA; 7.5\% solution), cholesterol lipid concentrate $(250 \times)$, and penicillin-streptomycin were bought from Gibco/BRL, Life Technologies (Paisley, Scotland); BSA (fraction $\mathrm{V})$, percoll, HEPES, collagenase type I, $\left.(\mathrm{Bu})_{2} \mathrm{CAMP}\right)$, ovine FSH, 22R-hydroxycholesterol (22R-OHC), and hCG were obtained from Sigma Chemical Co. (St. Louis, MO, USA). MEHP were purchased from TCI Europe (Brussels, Belgium).

\section{ANIMALS}

The testes and ovaries from 20-day-old Sprague-Dawley rats (B\&K Laboratories, Sollentuna, Sweden) were used for the isolation of immature granulosa cells and Leydig cell progenitors. These animals had access to a standard laboratory chow (Lantmännen, Kimstad, Sweden) and water ad libitum. The rats were anesthetized by phenobarbital before the testes and ovaries were removed. These experiments were approved by the Northern Stockholm Animal Ethics Committee (registration no. N319/08).

\section{ISOLATION AND PRIMARY CULTURE OF LEYDIG CELLS}

Leydig cell precursors were prepared from the testes of 20-day-old rats as described previously (Svechnikov et al., 2001). Briefly, following decapsulation, testes were disrupted by collagenase treatment and the seminiferous tubules were separated mechanically. In order to obtain purified Leydig cells, this crude suspension was loaded on top of a discontinuous gradient consisting of layers of $20,40,60$, and $90 \%$ percoll dissolved in HBSS and subsequently centrifuged at $800 \times g$ for $20 \mathrm{~min}$. The fractions enriched in Leydig cells thus obtained were then placed onto a continuous, self-generating density gradient formed from a $60 \%$ solutions of percoll and centrifuged at $20,000 \times g$ for $30 \mathrm{~min}$ at $4^{\circ} \mathrm{C}$.

The purity of the resulting Leydig cell preparations was shown to be $90 \%$, as determined by histochemical staining for $3 \beta-$ hydroxysteroid dehydrogenase (Payne et al., 1980). The cell viability, as assessed by Trypan blue exclusion, was routinely greater than $90 \%$. These purified Leydig cells were then resuspended in DMEM-F12 supplemented with $15 \mathrm{mM}$ HEPES (pH 7.4), $1 \mathrm{mg} / \mathrm{ml}$ BSA, $365 \mathrm{mg} / \mathrm{l}$ glutamine, $100 \mathrm{IU} / \mathrm{ml}$ penicillin, and $100 \mu \mathrm{g} / \mathrm{ml}$ streptomycin.

For culturing, $100 \mu \mathrm{l}$ of a suspension containing $1.5 \times 10^{5}$ cells/ $\mathrm{ml}$ was plated into each well of a 96-well Falcon plate (Falcon, Franklin Lakes, NJ, USA) and cultured for $2 \mathrm{~h}$ and thereafter incubated with or without MEHP $(100$ and $250 \mu \mathrm{M})$ for $24 \mathrm{~h}$ at $34^{\circ} \mathrm{C}$ in atmosphere of air and $5 \% \mathrm{CO}_{2}$. Pilot experiments have shown that these concentrations are non-cytotoxic and optimal for exploring effects of the mono-phthalate on Leydig cell steroidogenesis. At this time-point, culture medium was replaced by medium containing MEHP at the same concentrations and an optimal concentration of hCG $(10 \mathrm{ng} / \mathrm{ml})$ and/or $(\mathrm{Bu})_{2}$ cAMP $(1 \mathrm{mM})$ or $22 \mathrm{R}-\mathrm{OHC}(10 \mu \mathrm{M})$ for another $24 \mathrm{~h}$.

\section{ISOLATION AND PRIMARY CULTURE OF GRANULOSA CELLS}

Granulosa cells were isolated from the ovaries of untreated immature (20-day-old) female Sprague-Dawley rats (B\&K Laboratories,
Sollentuna, Sweden) as described previously (Svechnikova et al., 2007). In brief, after trimming away surrounding tissue, the ovaries were placed in 3 ml DMEM:F-12 (1:1) medium supplemented with penicillin $(100 \mathrm{U} / \mathrm{ml})$, streptomycin $(100 \mu \mathrm{g} / \mathrm{ml})$, and $0.5 \%$ BSA and thereafter punctured with a 25 -gage needle. The resulting cell suspension was then filtered through a $70-\mu \mathrm{M}$ cell strainer, followed by collection of cells by centrifugation at $200 \times g$ for $7 \mathrm{~min}$. After washing once with the same medium the cells were resuspended in a corresponding volume of fresh DMEM:F-12 (1:1) medium containing cholesterol lipid concentrate (diluted 1:250; intended to mimic the cholesterol content of the follicular fluid in vivo).

For culturing, $100 \mu \mathrm{l}$ of a suspension containing $1 \times 10^{5}$ cells $/ \mathrm{ml}$ was plated into each well of a 96-well Falcon plate and cultured for $2 \mathrm{~h}$ and thereafter incubated with or without MEHP (100 and $250 \mu \mathrm{M})$ for $24 \mathrm{~h}$ at $37^{\circ} \mathrm{C}$ in an atmosphere of air and $5 \% \mathrm{CO}_{2}$. Then, culture medium was replaced by fresh medium containing MEHP at the same concentrations and an optimal concentration of FSH $(50 \mathrm{mU} / \mathrm{ml})$ and $/$ or $(\mathrm{Bu})_{2}$ cAMP $(1 \mathrm{mM})$ for another $24 \mathrm{~h}$.

\section{STEROID ASSAYS}

Media from the cultures performed as described above were stored at $-20^{\circ} \mathrm{C}$ prior to analysis of testosterone, progesterone and $5 \alpha-$ androstane- $3 \alpha, 17 \beta$-diol ( $3 \alpha$-Adiol). The sum of the levels of testosterone and $3 \alpha$-Adiol, the predominant steroids synthesized by Leydig cell precursors, was used as an indicator of the total capacity of these immature steroidogenic cells to produce androgens in culture. Testosterone and progesterone were quantified employing the Coat-a-Count RIA kit (Diagnostic Products Corp., Los Angeles, CA, USA), in accordance with the manufacturer's instructions; while the levels of $3 \alpha$-Adiol were determined by RIA using specific antisera (Cosmo Bio Co. Ltd., Tokyo, Japan). For this purpose, $5 \alpha-\left[9,11,-{ }^{3} \mathrm{H}(\mathrm{N})\right]$ androstane-3 $3,17 \beta$-diol (specific activity, $40 \mathrm{Ci} / \mathrm{mmol}$ ) was obtained from NEN Life Science Products (Boston, MA, USA). Intra-assay and inter-assay coefficients for testosterone and progesterone RIA were $5.0,3.5 \%$ and $6.4,3.9 \%$, respectively. The same parameters for $3 \alpha$-Adiol RIA were 10 and $6.9 \%$. The sensitivity of the RIAs was $0.04,0.02$, and $0.08 \mathrm{ng} / \mathrm{ml}$ for testosterone, progesterone and $5 \alpha$-androstane- $3 \alpha$, $17 \beta$-diol, respectively.

\section{WESTERN BLOT ANALYSIS}

The influence of MEHP on basal and $(\mathrm{Bu})_{2}$ cAMP-stimulated SF-1 and StAR expression was analyzed by PAGE/western blotting as described earlier (Svechnikov et al., 2008). For this purpose, both types of steroidogenic cells were washed twice with PBS and then lysed and sonicated in a buffer containing $62.5 \mathrm{mM}$ Tris- $\mathrm{Cl}$ ( $\mathrm{pH} 6.8$ ), 2\% SDS, $50 \mathrm{mM}$ dithiothreitol and $10 \%$ glycerol. Subsequently, the fraction thus solubilized was collected by removal of debris by centrifugation at $10,000 \times g$ for $6 \mathrm{~min}$ and the solubilized proteins $(50 \mu \mathrm{g}$ from each sample) resolved by electrophoresis on $10 \%$ SDS/polyacrylamide gels and thereafter transferred electrophoretically to Hybond-P polyvinylidene difluoride (PVDF) membranes (Amersham Pharmacia Biotech, Little Chalfont, Buckinghamshire, UK), using $25 \mathrm{mM}$ Tris-Cl, $185 \mathrm{mM}$ glycine, $\mathrm{pH}$ 8.3, containing $20 \%$ methanol. These membranes were routinely stained with $5 \%$ Ponceau 
$S$ in order to confirm equal transfer of the proteins. Only membranes with equal levels of proteins from all lanes were processed further.

Following this transfer, each membrane was incubated in blocking buffer (TBS-0.1\% Tween (TBST) containing 5\% nonfat dry milk) for $1 \mathrm{~h}$, followed by three washes with TBST $(3 \times 10 \mathrm{~min})$. Mouse monoclonal anti-SF-1 antibody (Perseus Proteomics, Tokyo, Japan) and polyclonal antisera directed against StAR (kindly provided by Dr. Stocco, Texas Tech University, USA; Clark et al., 1994) were used for incubation at a dilution of 1:500 and 1:3000, respectively in TBS containing 5\% non-fat dry milk overnight at $4^{\circ} \mathrm{C}$. Antibody against tubulin (mouse monoclonal IgG, 1:500; Santa Cruz Biotechnology, Santa Cruz, CA, USA) and actin (rabbit polyclonal IgG, Sigma-Aldrich, St. Louse, MO, USA) were used as an internal standard. After washing, the membranes were then incubated with secondary donkey anti-rabbit or sheep anti-mouse antibodies conjugated with horseradish peroxidase (Amersham Pharmacia Biotech) and the bands detected by incubation with ECL Plus ${ }^{\mathrm{TM}}$ western blotting agent (Amersham Pharmacia Biotech) and subsequent exposure to Hyperfilm ECL (Amersham Pharmacia Biotech). Finally, the ECL Hyperfilms were scanned with an HP Scan Jet 5100C and HP Precision scan software (Hewlett-Packard Sverige AB, Kista, Sweden) and the extent of antibody binding quantitated employing the NIH Image 1.57 software.

\section{STATISTICAL ANALYSIS}

The differences between various values were analyzed for statistical significance by one-way analysis of variance (ANOVA) followed by the Dunnett $t$-test, using the SigmaStat (v 3.00) package (SPSS, Inc, Chicago, IL, USA). $p<0.05$ was considered to be statistically significant.

\section{RESULTS \\ MEHP STIMULATES BASAL STEROIDOGENESIS IN IMMATURE GRANULOSA AND LEYDIG CELLS}

As depicted in Figure 1 both concentrations of MEHP (100 and $250 \mu \mathrm{M}$ ) activated steroid production by cultured immature granulosa cells and Leydig cell progenitors. The most effective concentration of MEHP $(250 \mu \mathrm{M})$ significantly (12-fold over untreated control, $p<0.05)$ stimulated testosterone and its metabolite production by Leydig cell progenitors and markedly (three-fold over control, $p<0.05$ ) enhanced progesterone secretion by immature granulosa cells.

\section{OPPOSITE EFFECT OF MEHP ON STEROIDOGENESIS BY CULTURED GRANULOSA AND LEYDIG CELL PROGENITORS IN RESPONSE TO FSH AND hCG}

We observed that MEHP enhanced FSH-stimulated progesterone production by granulosa cells, where the highest concentration of the phthalate $(250 \mu \mathrm{M})$ increased FSH-activated steroid production by two-fold compare to FSH alone ( $p<0.05$; Figure $2 \mathrm{~A})$. In contrast, the same concentration of MEHP significantly (by $48 \%$, $p<0.05)$ suppressed hCG-activated steroidogenesis in Leydig cell progenitors (Figure 2B).

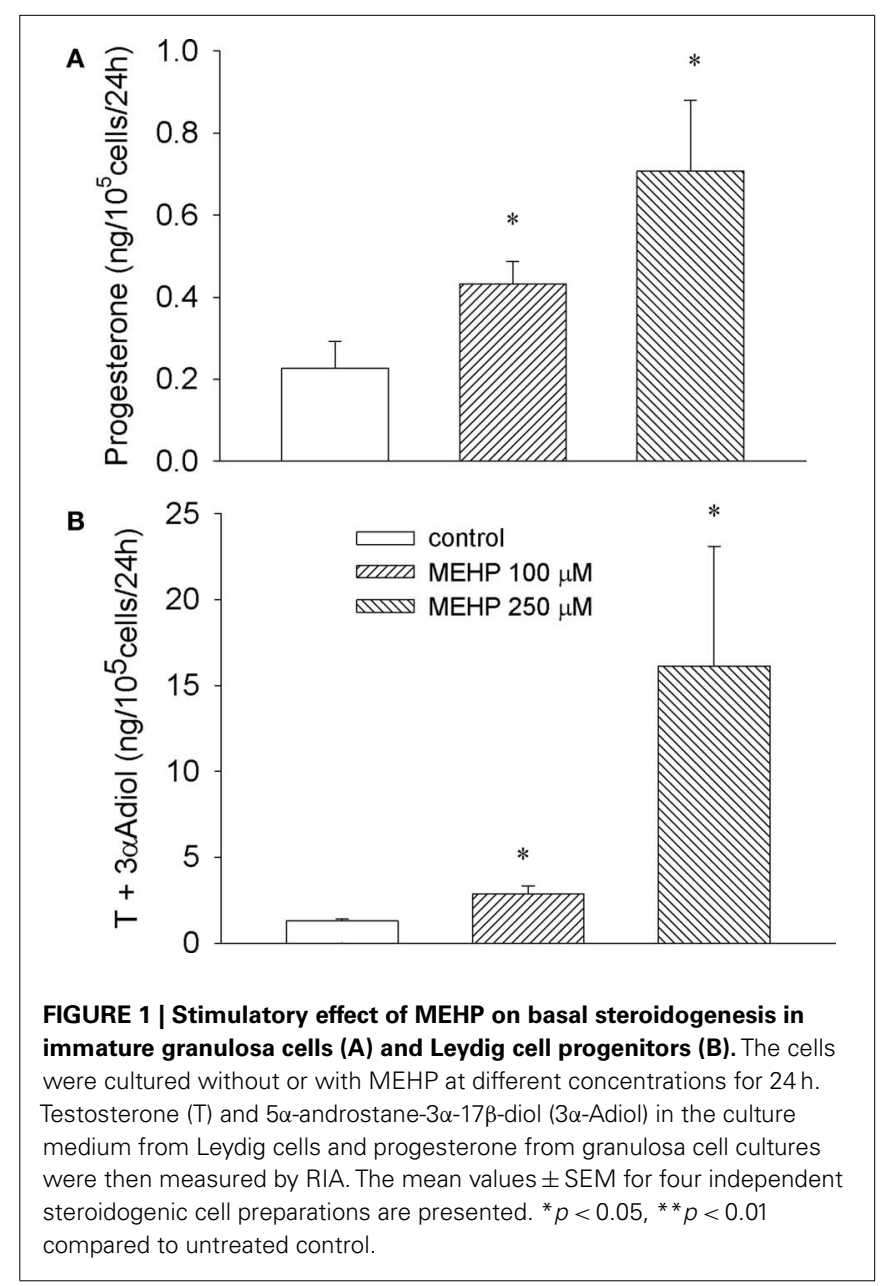

\section{OPPOSITE EFFECT OF MEHP ON (Bu) ${ }_{2}$ CAMP-ACTIVATED STEROIDOGENESIS IN GRANULOSA CELLS AND LEYDIG CELL PROGENITORS}

We further investigated whether MEHP can influence steroidogenesis in the steroidogenic cells stimulated by $(\mathrm{Bu})_{2} \mathrm{cAMP}$ beyond LH/FSH receptor. Similarly to FSH, MEHP significantly and dose-dependently promoted $(\mathrm{Bu})_{2}$ cAMP-stimulated progesterone production by immature granulosa cells (Figure 3A), while the responsiveness of Leydig cell progenitors to the stimulator was significantly (by $44 \%, p<0.05)$ attenuated by the highest $(250 \mu \mathrm{M})$ concentration of MEHP (Figure 3B). In contrast, MEHP exerted no significant effect on androgen synthesis from 22R-OHC, a derivative of cholesterol that diffuses readily across membranes (22R-OHC treatment, $153.7 \pm 1.2$ vs $139 \pm 7.4 \mathrm{ng} / 10^{5}$ cells $/ 24 \mathrm{~h}$ with 22R-OHC + MEHP treatment; $p=0.12, n=4$ ), suggesting that MEHP may disturb the translocation of cholesterol across mitochondrial membranes in Leydig cell progenitors.

\section{EFFECT OF MEHP ON STAR PROTEIN EXPRESSION IN GRANULOSA CELLS AND LEYDIG CELL PROGENITORS ACTIVATED BY $(\mathrm{Bu})_{2}$ CAMP}

We further tested the hypothesis that MEHP can differentially affect the expression of StAR (which is responsible for the translocation of cholesterol from the outer to the inner mitochondrial 


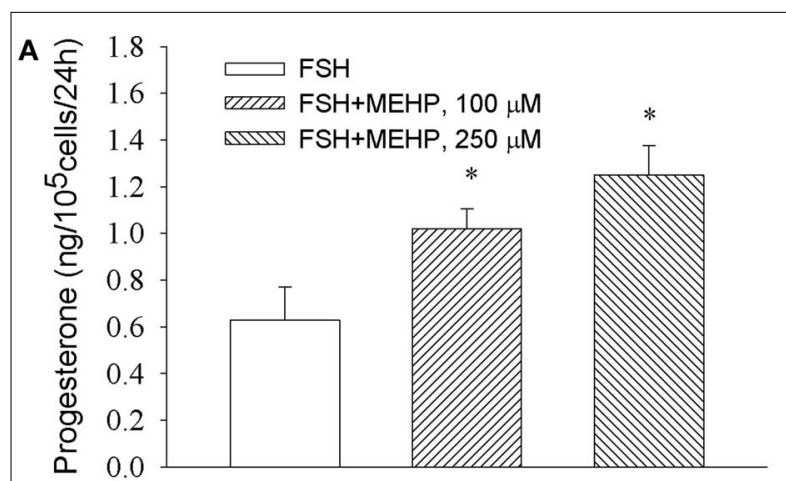

B

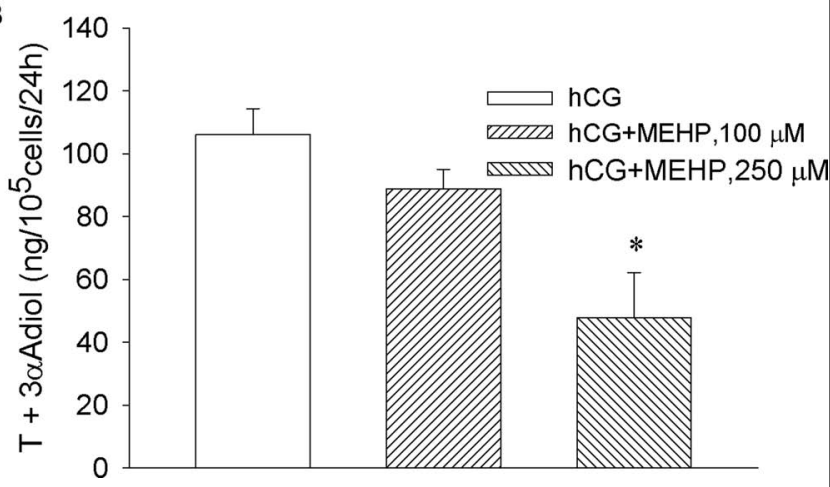

FIGURE 2 | Opposite effect of MEHP on FSH and hCG-stimulated steroidogenesis in immature granulosa cells $(A)$ and Leydig cell progenitors (B). The steroidogenic cells were cultured without or with MEHP at different concentrations for $24 \mathrm{~h}$ and then incubated with $\mathrm{hCG}$ $(10 \mathrm{ng} / \mathrm{ml})$ and $\mathrm{FSH}(50 \mathrm{mU} / \mathrm{ml})$ in the absence or presence of the same concentrations of MEHP for additional $24 \mathrm{~h}$. Testosterone (T) and $3 \alpha$-Adiol and progesterone in the culture medium were then measured by RIA. The mean values \pm SEM for four independent steroidogenic cell preparations are presented. ${ }^{*} p<0.05$ compared to treatment with FSH and hCG.

membrane; Clark et al., 1994) in granulosa cells and Leydig cell progenitors. As shown in Figure $4(\mathrm{Bu})_{2}$ cAMP alone significantly induced expression of StAR in both Leydig cell progenitors and granulosa cells (by 20- and 9-fold, respectively, $p<0.01$ ). Cotreatment with both $(\mathrm{Bu})_{2}$ cAMP and MEHP further markedly enhanced StAR expression in both types of steroidogenic cells. Moreover, MEHP alone was found to stimulate basal StAR expression in Leydig cell progenitors and granulosa cells (by 11- and 4-fold, respectively, $p<0.01)$.

\section{EFFECT OF MEHP ON SF-1 PROTEIN EXPRESSION IN GRANULOSA CELLS AND LEYDIG CELL PROGENITORS ACTIVATED BY (Bu) ${ }_{2}$ CAMP}

Since StAR expression is regulated by transcription factor SF-1, we also investigated the effect of MEHP on SF-1 expression in cAMP-activated immature granulosa and Leydig cells. Our data demonstrated that in contrast to Leydig cells, unstimulated and MEHP-treated granulosa cells were not able to express detectable amount of SF-1 protein (Figure 5). However, stimulation with $(\mathrm{Bu})_{2}$ cAMP significantly activated SF-1 expression in both types of cells, a cellular process that was suppressed by MEHP in Leydig but not granulosa cells.

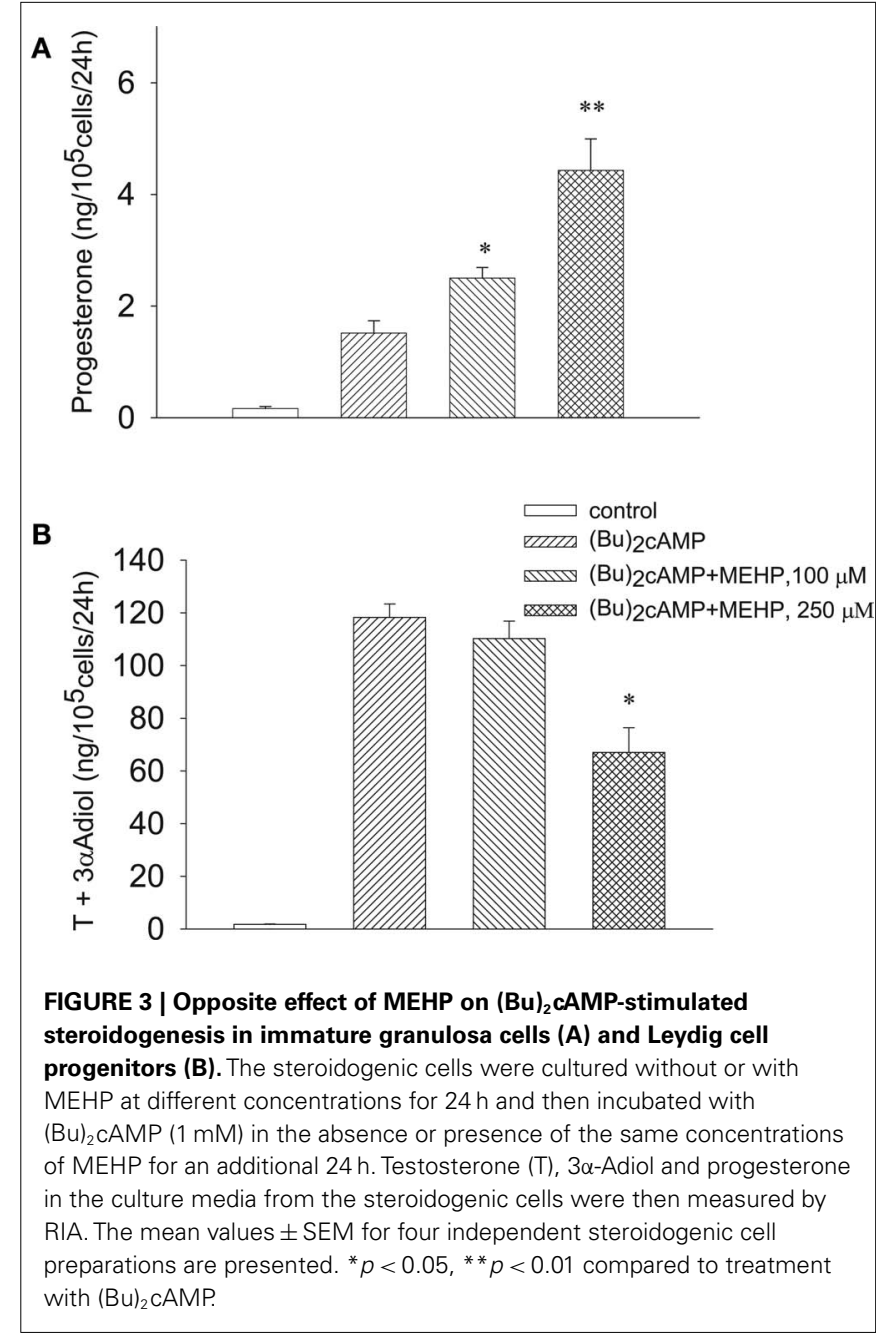

\section{DISCUSSION}

Here we demonstrate for the first time that MEHP exerts genderspecific adverse effects on steroidogenesis by immature granulosa cells and Leydig cell progenitors isolated from 20-day-old rats. This mono-phthalate significantly stimulated basal steroidogenesis in both types of steroidogenic cells, while gonadotropin (FSH and hCG) and (Bu) $)_{2}$ CAMP-activated steroid production was differently affected by the phthalate in male and female cells. We observed that MEHP caused an additive effect on the stimulator activated progesterone biosynthesis by granulosa cells but attenuated significantly hCG and $(\mathrm{Bu})_{2}$ cAMP-evoked steroidogenesis in Leydig cell progenitors. The observation that MEHP had no effect on steroidogenesis stimulated by 22R-OHC, a form of cholesterol that readily penetrates mitochondrial membranes, indicates that MEHP may act by disturbing cholesterol trafficking across mitochondrial membranes and influence StAR expression in Leydig cell progenitors. Indeed, further analysis of StAR expression demonstrated that MEHP enhanced $(\mathrm{Bu})_{2} \mathrm{cAMP}$-activated StAR expression in both male and female steroidogenic cells, an event accompanied by activation of progesterone production in granulosa cells and inhibition of steroidogenesis in Leydig cell progenitors. 


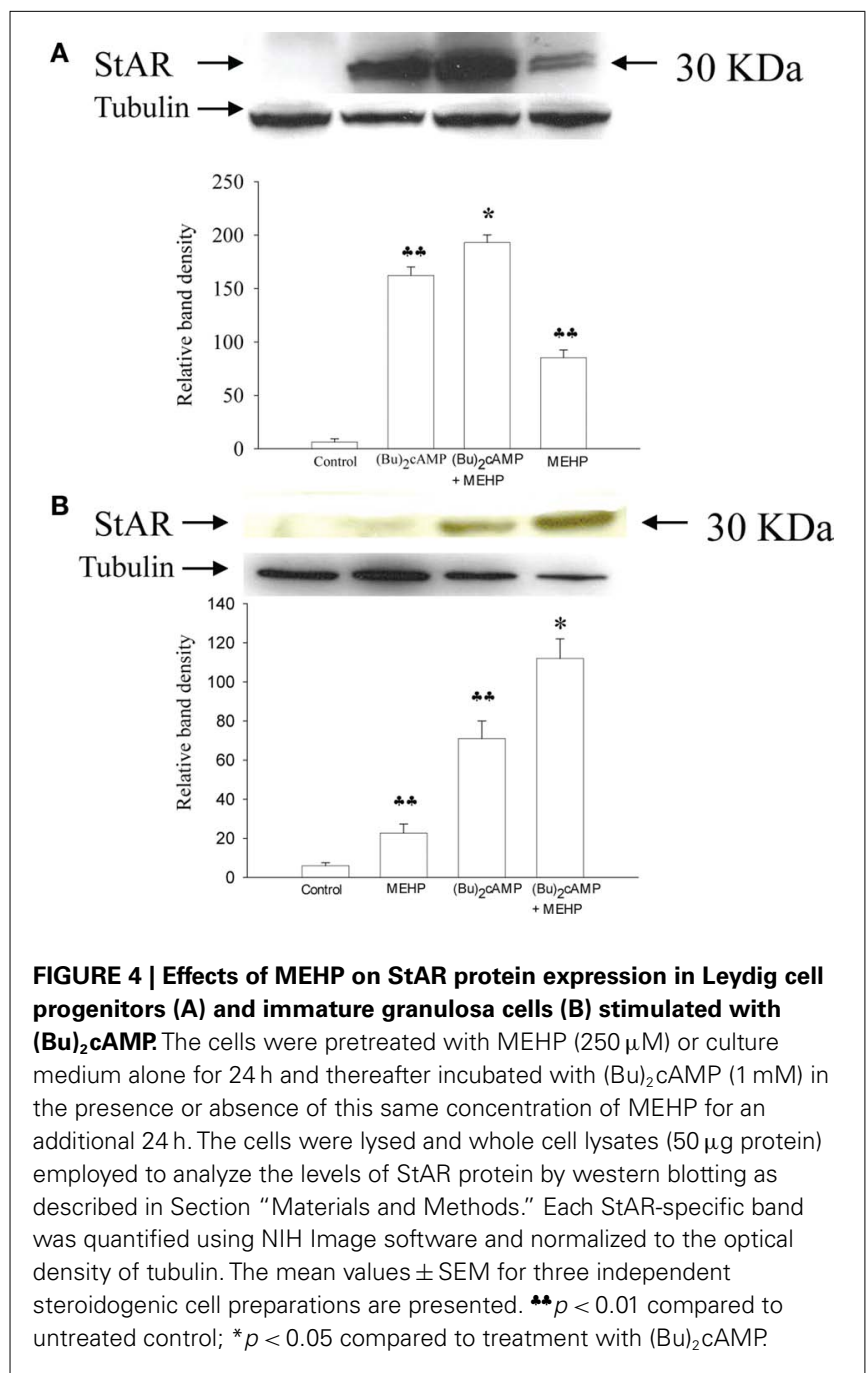

In addition, we also found that cAMP-PKA signaling activated by $(\mathrm{Bu})_{2}$ cAMP up-regulated SF-1 expression in both types of the cells, a cellular event that was suppressed by MEHP in Leydig but not in granulosa cells.

Our present findings are in line with those of a recent study showing that MEHP stimulates basal steroid synthesis in KK-1 granulosa tumor cells and in mouse Leydig tumor cells (MLTC-1) but suppresses hCG-induced progesterone production in MLTC-1. The observed stimulatory effect of MEHP was StAR independent and associated with an up-regulation of the enzymes involved in cholesterol mobilization, suggesting that MEHP increases the amount of cholesterol available for steroidogenesis (Gunnarsson et al., 2008). In contrast, we found that MEHP significantly stimulated StAR expression in both types of gonadal cells, a process associated with the activation of steroidogenesis. This difference in the mechanisms responsible for the activation of steroidogenesis by MEHP in the steroidogenic cells may be explained by different experimental models used in our study and that by Gunnarsson et al. (2008). In our study we employed primary cultures of native immature steroidogenic cells, while Gunnarsson et al. (2008) exploited steroidogenic tumor cells which may

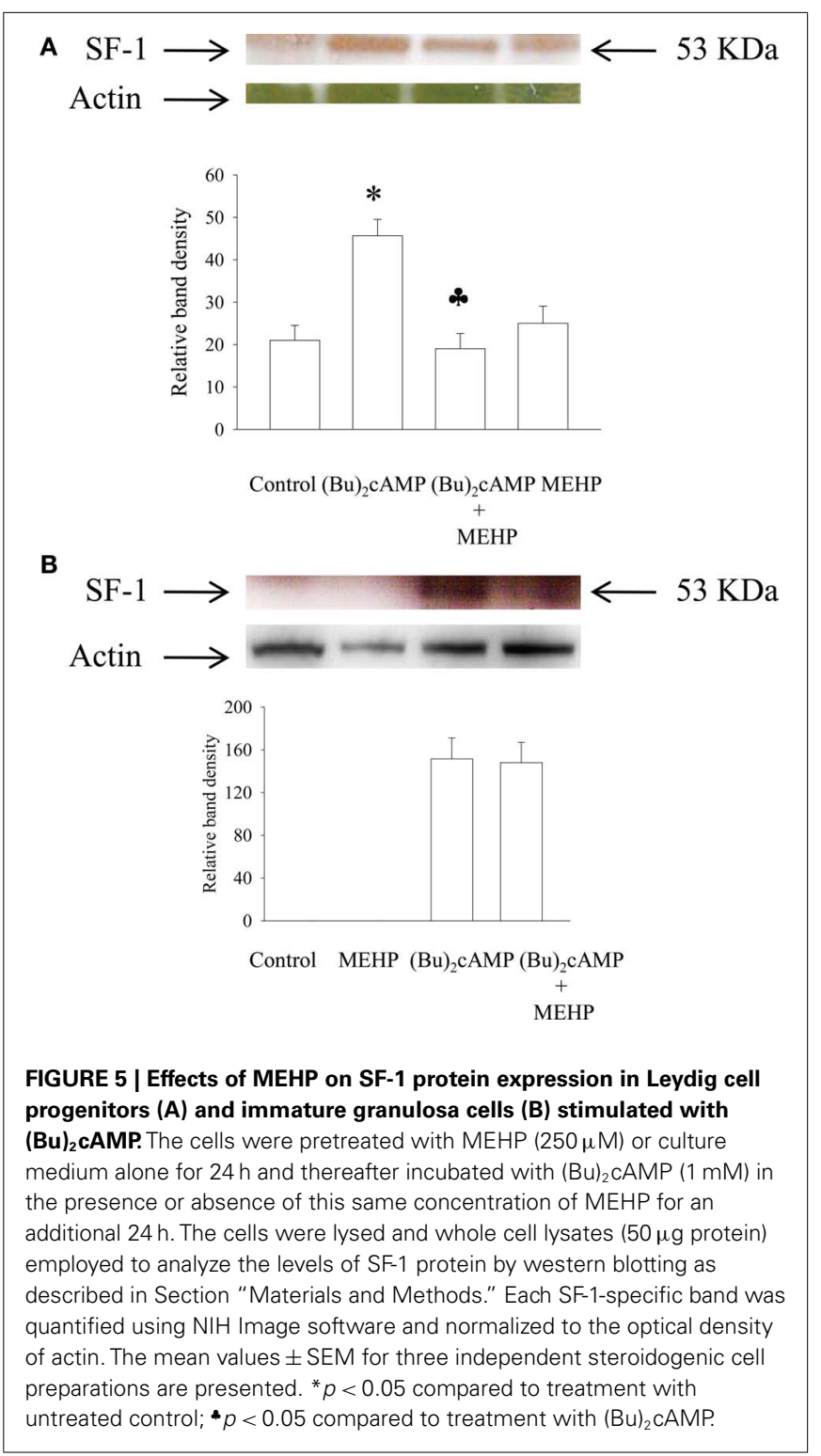

have an aberrant steroidogenic machinery and signal transduction pathway(s). Moreover, our findings agree well with another recent study demonstrating that exposure to MEHP increased StAR gene expression in the rat testis (Lahousse et al., 2006).

We also observed that $(\mathrm{Bu})_{2} \mathrm{cAMP}$-activated expression of StAR was significantly up-regulated by MEHP in both types of steroidogenic cells. These events were associated with a decrease in androgen production by Leydig cell progenitors and activation of steroidogenesis in granulosa cells. This finding let us to suggest that molecular events activated by MEHP in the $(\mathrm{Bu})_{2}$ cAMPstimulated steroidogenic cells and triggered StAR gene expression were similar in both types of cells but post-translational modifications of StAR which activate its function were suppressed in Leydig cell progenitors. It is well-known that StAR needs to be phosphorylated to reach maximal activity, a process dependent on the action of the PKA pathway (Arakane et al., 1997). Therefore, attenuation of StAR protein phosphorylation but not its expression in Leydig 
cell progenitors co-treated with MEHP and $(\mathrm{Bu})_{2}$ cAMP may result in accumulation of functionally inactive StAR with low capacity to deliver cholesterol into the mitochondria. In contrast, StAR function and steroidogenesis were activated in granulosa cells cotreated with MEHP and $(\mathrm{Bu})_{2} \mathrm{CAMP}$, indicating that this phthalate did not counteract post-translational modifications induced by cAMP-PKA dependent signaling pathway in the female cells. In addition, we have recently demonstrated that MEHP decreased hCG-activated StAR protein expression, a process that was associated with reduced transport of cholesterol into mitochondria and attenuated androgen production in immature and adult Leydig cells (Svechnikov et al., 2008).

Our data have also shown that the activation of StAR expression by cAMP-PKA signaling was associated with up-regulation of SF-1 expression in both types of steroidogenic cells, a finding that is in line with previous report (Sandhoff et al., 1998). However, in contrast to StAR, co-treatment with $(\mathrm{Bu})_{2}$ cAMP and MEHP attenuated SF-1 expression in Leydig cells and had no significant effect on the transcription factor level in granulosa cells. This observed disagreement between StAR and SF-1 expression can be explained by a complex regulation of StAR expression in steroidogenic cells that includes dynamic and effective interaction between several transcription factors (e.g., SF-1, CREB, GATA, cJun) and coactivators (Stocco and Clark, 1996; Stocco, 2001), where SF-1 may not play a primary role. This suggestion is supported by one recent study showing that attenuation of the expression of SF-1-regulated genes (e.g., StAR, P450scc, P450c17) in the fetal testis of rats that underwent di (n-butyl) phthalate (DBP) exposure in utero was not associated with changes in SF-1 mRNA and protein levels, suggesting that this downregulation was indirect and perhaps involved cofactor starvation (Plummer et al., 2007). Moreover, (Bu) $)_{2}$ cAMP and ciglitazone stimulated StAR expression in immortalized KK1 mouse granulosa cells and MA-10 mouse Leydig tumor cells was linked to activation of PPAR $\gamma$ and up-regulation of cJun expression but not SF-1 (Kowalewski et al., 2009). We also observed that basal and MEHP-treated granulosa cells did not express detectable amount of SF-1. This finding may be due to weak steroidogenic activity of immature granulosa cells compare to Leydig cells, which in our experiments reached 10- to 20-fold differences, suggesting that SF-1 is not a major player in the regulation of basal granulosa cell steroidogenesis.

The concentrations of MEHP (100 and $250 \mu \mathrm{M})$ employed in the present in vitro investigation are relevant to in vivo situations in humans. Human exposure to DEHP can be as high as $4.3 \mathrm{mg} / \mathrm{kg} /$ day for adults (Lovekamp-Swan and Davis, 2003) and $10-20 \mathrm{mg} / \mathrm{kg} /$ day for infants exposed to neonatal transfusion or parenteral nutrition (Loff et al., 2000; Calafat et al., 2004), resulting in 150 and $400 \mu \mathrm{M}$ concentrations in the blood, respectively.

In our present study we have used primary cultures of steroidogenic cells isolated from 20-day-old rats to explore the effects of MEHP. This age represents prepubertal stage of human development. Phthalates are widely used as plasticizers in the production

\section{REFERENCES}

Akingbemi, B. T., Youker, R. T., Sottas,

C. M., Ge, R., Katz, E., Klinefelter,

G. R., Zirkin, B. R., and Hardy, M.
P. (2001). Modulation of rat Leydig cell steroidogenic function by $\operatorname{di}(2-$ ethylhexyl)phthalate. Biol. Reprod. 65, 1252-1259.

of plastics and children are thought to be more susceptible for harmful action of these anthropogenic chemicals than adults. Recent studies reported the negative correlation between AGD and maternal (urinary) levels of phthalates in male infants (Swan et al., 2005; Swan, 2008). Moreover, these studies also demonstrated that AGD correlated to penile volume and the incidence of cryptorchidism (Swan et al., 2005). Additionally, phthalates present in breast milk are proposed to alter the function of the hypothalamicpituitary-gonadal axis in male offspring (Main et al., 2006). However, it should be noted that negative effect of MEHP on testicular steroidogenesis in human fetal testis is not yet proven. One in vitro study reported that this phthalate had no effect on basal and LH-stimulated steroidogenesis in first-trimester human fetal testis explant (Lambrot et al., 2009).

Alteration in steroidogenesis during development may significantly affect the reproductive health of children. Pubertal development is closely regulated by sex hormones in both sexes and activation or suppression of steroidogenesis may induce hormonal disturbances resulting in pathological conditions. For example, increased production of progesterone by MEHP stimulated granulosa cells may induce their advanced luteinization, a process that may lead to dysregulation of the estrous cycle and anovulatory cycles in rats (Davis et al., 1994). Further, in this context, a recent study demonstrated that exposure of prepubertal rats to low environmentally relevant DEHP levels for 28 days increased Leydig cell capacity to produce testosterone that was associated with enhanced plasma levels of LH (Akingbemi et al., 2001), indicating potential for phthalates to modulate the pituitary-testicular axis in rodents. Similarly, we have recently reported that the ability of primary cultures of pituitary cells isolated from DEHP-treated prepubertal female rats to produce $\mathrm{LH}$ in response to $\mathrm{GnRH}$ was significantly enhanced (Svechnikova et al., 2007).

Taken together, our current data indicate that MEHP affects gonadal steroidogenesis in a gender-specific manner. This phthalate stimulated basal steroidogenesis and StAR expression in both male and female steroidogenic cells. However, when MEHP was incubated with $(\mathrm{Bu})_{2} \mathrm{cAMP}$, steroid production was increased in granulosa cells and suppressed in Leydig cell progenitors, a process associated with up-regulation of StAR expression. Based on these results it may be hypothesized that males and females react differentially to the endocrine disrupting actions of phthalates, with boys being more susceptible than girls. This may be related to the clinical observation that DSD are more prevalent in boys than girls.

\section{ACKNOWLEDGMENTS}

This work was supported financially by the EU Commission (CASCADE NoE FOOD-CT-2004-506319; PIONEER STREP FOODCT-2005-513991), the Swedish Research Council (No. 2002-5892), the Swedish Environmental Protection Agency (ReproSafe), the Swedish Children's Cancer Fund, the Frimurare Barnhuset Foundation in Stockholm, Sällskapet Barnavård, Stiftelsen Samariten, and Karolinska Institute.

Arakane, F., King, S. R., Du, Y., Kallen, C. B., Walsh, L. P., Watari, H., Stocco, D. M., and Strauss, J. F. III. (1997). Phosphorylation of steroidogenic acute regulatory protein (StAR) modulates its steroidogenic activity. J. Biol. Chem. 272, 32656-32662. 
Blount, B. C., Silva, M. J., Caudill, S. P., Needham, L. L., Pirkle, J. L., Sampson, E. J., Lucier, G. W., Jackson, R. J., and Brock, J. W. (2000). Levels of seven urinary phthalate metabolites in a human reference population. Environ. Health Perspect. 108, 979-982.

Brock, J. W., Caudill, S. P., Silva, M. J., Needham, L. L., and Hilborn, E. D. (2002). Phthalate monoesters levels in the urine of young children. Bull. Environ. Contam. Toxicol. 68, 309-314.

Calafat, A. M., Needham, L. L., Silva, M. J., and Lambert, G. (2004). Exposure to di-(2-ethylhexyl) phthalate among premature neonates in a neonatal intensive care unit. Pediatrics 113, e429-e434.

Clark, B. J., Wells, J., King, S. R., and Stocco, D. M. (1994). The purification, cloning, and expression of a novel luteinizing hormone-induced mitochondrial protein in MA-10 mouse Leydig tumor cells. Characterization of the steroidogenic acute regulatory protein (StAR). J. Biol. Chem. 269, 28314-28322.

Davis, B. J., Maronpot, R. R., and Heindel, J. J. (1994). Di-(2-ethylhexyl) phthalate suppresses estradiol and ovulation in cycling rats. Toxicol. Appl. Pharmacol. 128, 216-223.

Dees, J. H., Gazouli, M., and Papadopoulos, V. (2001). Effect of mono-ethylhexyl phthalate on MA-10 Leydig tumor cells. Reprod. Toxicol. 15, 171-187.

Dostal, L. A., Chapin, R. E., Stefanski, S. A., Harris, M. W., and Schwetz, B. A. (1988). Testicular toxicity and reduced Sertoli cell numbers in neonatal rats by $\mathrm{di}(2-$ ethylhexyl)phthalate and the recovery of fertility as adults. Toxicol. Appl. Pharmacol. 95, 104-121.

Gray, L. E., Ostby, J., Furr, J., Wolf, C. J., Lambright, C., Parks, L., Veeramachaneni, D. N., Wilson, V., Price, M., Hotchkiss, A., Orlando, E., Guillette, L., Ashby, J., Gray, E., Grumbach, M., Sultan, C., Morris, I., and Bro-Rasmussen, F. (2001). Effects of environmental antiandrogens on reproductive development in experimental animals. Hum. Reprod. Update 7, 248-264.

Gunnarsson, D., Leffler, P., Ekwurtzel, E., Martinsson, G., Liu, K., and Selstam, G. (2008). Mono-(2ethylhexyl) phthalate stimulates basal steroidogenesis by a cAMPindependent mechanism in mouse gonadal cells of both sexes. Reproduction 135, 693-703.

Jones, H. B., Garside, D. A., Liu, R., and Roberts, J. C. (1993). The influence of phthalate esters on Leydig cell structure and function in vitro and in vivo. Exp. Mol. Pathol. 58, 179-193.

Koch, H. M., Preuss, R., and Angerer, J. (2006). Di(2-ethylhexyl)phthalate (DEHP): human metabolism and internal exposure - an update and latest results. Int. J. Androl. 29, 155-165; discussion 181-155.

Kowalewski, M. P., Dyson, M. T., Manna, P. R., and Stocco, D. M. (2009). Involvement of peroxisome proliferator-activated receptor gamma in gonadal steroidogenesis and steroidogenic acute regulatory protein expression. Reprod. Fertil. Dev. 21, 909-922.

Lahousse, S. A., Wallace, D. G., Liu, D., Gaido, K. W., and Johnson, K. J. (2006). Testicular gene expression profiling following prepubertal rat mono-(2-ethylhexyl) phthalate exposure suggests a common initial genetic response at fetal and prepubertal ages. Toxicol. Sci. 93, 369-381.

Lambrot, R., Muczynski, V., Lecureuil, C., Angenard, G., Coffigny, H., Pairault, C., Moison, D., Frydman, R., Habert, R., and RouillerFabre, V. (2009). Phthalates impair germ cell development in the human fetal testis in vitro without change in testosterone production. Environ. Health Perspect. 117, 32-37.

Loff, S., Kabs, F., Witt, K., Sartoris, J., Mandl, B., Niessen, K. H., and Waag, K. L. (2000). Polyvinylchloride infusion lines expose infants to large amounts of toxic plasticizers. J. Pediatr. Surg. 35, 1775-1781.

Lottrup, G., Andersson, A. M., Leffers, H., Mortensen, G. K., Toppari, J., Skakkebaek, N. E., and Main, K. M. (2006). Possible impact of phthalates on infant reproductive health. Int. J. Androl. 29, 172-180; discussion 181-175.

Lovekamp, T. N., and Davis, B. J. (2001). Mono-(2-ethylhexyl) phthalate suppresses aromatase transcript levels and estradiol production in cultured rat granulosa cells. Toxicol. Appl. Pharmacol. 172, 217-224.
Lovekamp-Swan, T., and Davis, B. J. (2003). Mechanisms of phthalate ester toxicity in the female reproductive system. Environ. Health Perspect. 111, 139-145.

Main, K. M., Mortensen, G. K., Kaleva, M. M., Boisen, K. A., Damgaard, I. N., Chellakooty, M., Schmidt, I. M., Suomi, A. M., Virtanen, H. E., Petersen, D. V., Andersson, A. M., Toppari, J., and Skakkebaek, N. E. (2006). Human breast milk contamination with phthalates and alterations of endogenous reproductive hormones in infants three months of age. Environ. Health Perspect. 114, 270-276.

Payne, A. H., Downing, J. R., and Wong, K. L. (1980). Luteinizing hormone receptors and testosterone synthesis in two distinct populations of Leydig cells. Endocrinology 106, 1424-1429.

Plummer, S., Sharpe, R. M., Hallmark, N., Mahood, I. K., and Elcombe, C. (2007). Time-dependent and compartment-specific effects of in utero exposure to di(n-butyl) phthalate on gene/protein expression in the fetal rat testis as revealed by transcription profiling and laser capture microdissection. Toxicol. Sci. 97 , 520-532.

Sandhoff, T. W., Hales, D. B., Hales, K. H., and McLean, M. P. (1998). Transcriptional regulation of the rat steroidogenic acute regulatory protein gene by steroidogenic factor 1. Endocrinology 139, 4820-4831.

Sjoberg, P., Bondesson, U., Gray, T. J., and Ploen, L. (1986). Effects of di-(2ethylhexyl) phthalate and five of its metabolites on rat testis in vivo and in in vitro. Acta Pharmacol. Toxicol. (Copenh) 58, 225-233.

Stocco, D. M. (2001). StAR protein and the regulation of steroid hormone biosynthesis. Annu. Rev. Physiol. 63, 193-213.

Stocco, D. M., and Clark, B. J. (1996). Regulation of the acute production of steroids in steroidogenic cells. Endocr. Rev. 17, 221-244.

Svechnikov, K., Svechnikova, I., and Soder, O. (2008). Inhibitory effects of mono-ethylhexyl phthalate on steroidogenesis in immature and adult rat Leydig cells in vitro. Reprod. Toxicol. 25, 485-490.

Svechnikov, K. V., Sultana, T., and Söder, O. (2001). Age-dependent stimulation of Leydig cell steroidogenesis by interleukin-1 isoforms. Mol. Cell. Endocrinol. 182, 193-201.

Svechnikova, I., Svechnikov, K., and Soder, O. (2007). The influence of di-(2-ethylhexyl) phthalate on steroidogenesis by the ovarian granulosa cells of immature female rats. J. Endocrinol. 194, 603-609.

Swan, S. H. (2008). Environmental phthalate exposure in relation to reproductive outcomes and other health endpoints in humans. Environ. Res. 108, 177-184.

Swan, S. H., Main, K. M., Liu, F., Stewart, S. L., Kruse, R. L., Calafat, A. M. Mao, C. S., Redmon, J. B., Ternand, C. L., Sullivan, S., and Teague, J. L. (2005). Decrease in anogenital distance among male infants with prenatal phthalate exposure. Environ. Health Perspect. 113, 1056-1061.

Thomas, J. A., and Thomas, M. J. (1984). Biological effects of di(2-ethylhexyl) phthalate and other phthalic acid esters. Crit. Rev. Toxicol. 13, 283-317.

Treinen, K. A., Dodson, W. C., and Heindel, J. J. (1990). Inhibition of FSH-stimulated cAMP accumulation and progesterone production by mono(2-ethylhexyl) phthalate in rat granulosa cell cultures. Toxicol. Appl. Pharmacol. 106, 334-340.

Conflict of Interest Statement: The authors declare that the research was conducted in the absence of any commercial or financial relationships that could be construed as a potential conflict of interest.

Received: 18 January 2011; accepted: 07 April 2011; published online: 25 April 2011.

Citation: Svechnikov K, Svechnikova I and Söder O (2011) Gender-specific adverse effects of mono-ethylhexyl phthalate on steroidogenesis in immature granulosa cells and rat Leydig cell progenitors in vitro. Front. Endocrin. 2:9. doi: 10.3389/fendo.2011.00009

This article was submitted to Frontiers in Pediatric Endocrinology, a specialty of Frontiers in Endocrinology.

Copyright (C) 2011 Svechnikov, Svechnikova and Söder. This is an open-access article subject to a non-exclusive license between the authors and Frontiers Media $S A$, which permits use, distribution and reproduction in other forums, provided the original authors and source are credited and other Frontiers conditions are complied with 